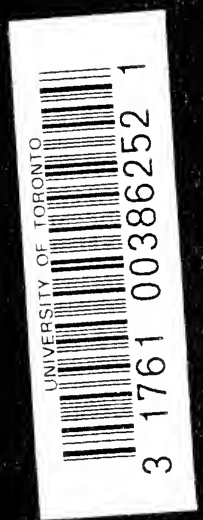

13

1201

G54R4 


$$
\text { . }
$$





\section{JOSEPH GLANVILL}




\section{WORKS BY H. STANLEY REDGROVE}

B.Sc. (Lond.), F.C.S.

ON THE CALCULATION OF THERMO-CHEMICAL CONSTANTS. (Arnold, 1909, 6s. net.)

MATTER, SPIRIT AND THE COSMOS: Some Suggestions towards a better Understanding of the Whence and Why of their Existence. (Rider, Popular Edition, 1916, 1s. net.)

ALCHEMY : ANCIENT AND MODERN. Being a brief Account of the Alchemistic Doctrines and their Relacions, to Mysticism on the one Hand, and to recent Discoveries in Pnysical Science on the other Hand; together with some Particulars regarding the Iives and Teachings of the most noted Alchemists. (Rider, 1911.)

A MATHEMATICAL THEORY OF SPIRIT. Being an Attempt to employ certain Mathematical Principles in the Elucidation of some Metaphysical Problems. (Rider, 1912, $2 s .6 d$. net.)

EXPERIMENTAL MENSURATION. An Elementary Textbook of Inductive Geometry. (Heinemann, 1912, 2s. 6d. net.)

THE MAGIC OF EXPERIENCE. A Contribution to the Theory of Knowledge. (With an Introduction by Sir William F. Barrett, F.R.S.) (Dent, 1915, out of print.)

BYGONE BELIEFS. A Series of Excursions in the Byways of Thought. (Rider, 1920, 10s. 6d.net.)

PURPOSE AND TRANSCENDENTALISM. An Exposition of Swedenborg's Philosophical Doctrines in Relation to Modern Thought. (Kegan Paul, 1920, 5 s. net.)

ROGER BACON, the Father of Experimental Science, and Mediæval Occultism. (Rider, 1920, 1s. 6d. net..)

INDUSTRIAL GASES, together with the Liquefaction of Gases. By various authors, including $\mathrm{H}$. S. Redgrove. (Crosby Lockwood, Second Impression, 1918, 9s. net.)

THE INDICTMENT OF WAR. An Anthology. Compiled by H. S. Redgrove and J. H. Rowbottom. (Daniel, 1919, 10s. 6d. net.) 


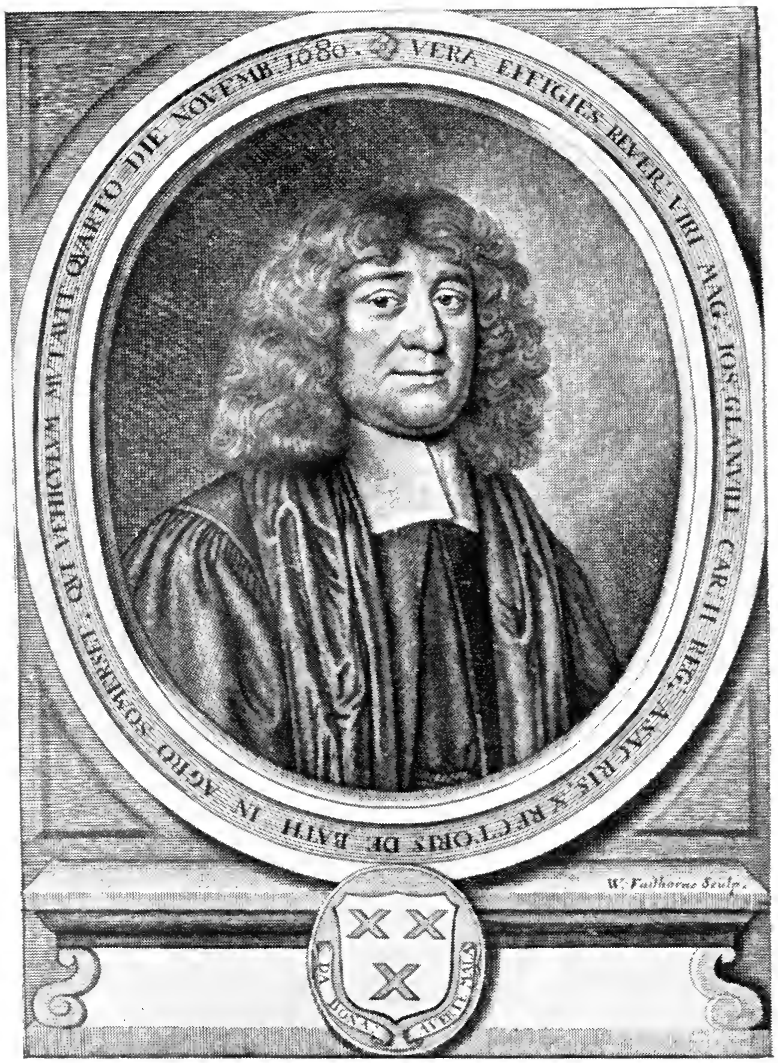

JOSEPH GLANVILL.

From an engraved portrait by William Faithorne.

(By permission of the British Ifuseum. Photo by D. Hac3eth London.) 


\title{
JOSEPH GLANVILL
}

AND PSYCHICAL RESEARCH IN THE SEVENTEENTH CENTURY

\author{
BY \\ H. STANLEY REDGROVE \\ B.Sc. (LOND.), F.C.S. \\ AND \\ I. M. L. REDGROVE
}

\section{LONDON \\ WILLIAM RIDER \& SON, LTD. 8-11 PATERNOSTER ROW, E.G.}

1921 


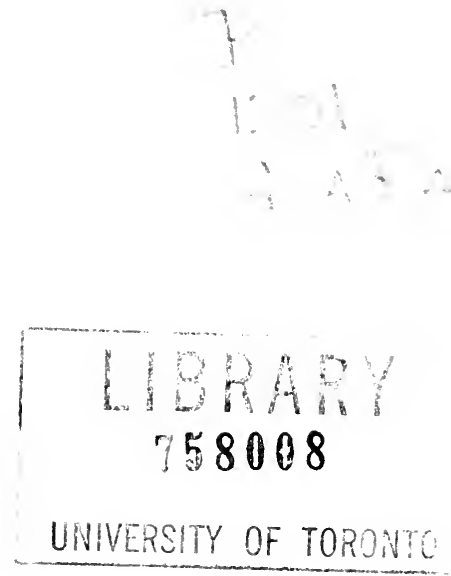




\section{O N T E T S}

\section{CHAPTER I}

$\begin{array}{ccc}\text { BIOGRAPHY } & \cdot & \cdot \\ & \text { CHAPTER II }\end{array}$

Scepticism • $\quad . \quad \cdot \quad \cdot \quad \cdot \quad \cdot \quad 23$

CHAPTER III

Platonism •

\section{CHAPTER IV}

The Royal Society -
CHAPTER V

Psychical Research: Preliminary Considerations $\quad . \quad . \quad . \quad . \quad 63$

\section{CHAPTER VI}

Psychical Research: Facts and Theories $. \quad . \quad . \quad . \quad .78$ 


\section{JOSEPH GLANVILL}

\section{CHAPTER I}

\section{BIOGRAPHY}

There is no century, perhaps, in English history that exhibits to our sight so many contrasts as does the seventeenth. Every age, no doubt, is a transition age, and every age exhibits change; but the seventeenth century may, in a very special sense, be characterised as a time of flux. It was an age of fervent religious enthusiasm, as also an age of licentiousness and indifference to religion. It was an age of gross superstition, as also an age in which the foundations of modern scientific knowledge were laid. There was war in the schools, between scholasticism, which for so many centuries had held sway over men's minds, and the new experimental and inductive philosophy which owed its origin to Bacon. There was also war in the land, the mind of the 
nation oscillating in a choice between republicanism and monarchism. We may perhaps look upon this outward strife and clash of political theories as, in a way, the manifestation and outcome of an inner and spiritual conflict. But from the vantage point of time we can avoid the error of imagining the political conflict as a contest between the powers of darkness on the one hand and those of light on the other. We can-indeed, we mustadmire the love of moral purity and hatred of hypocrisy in religion and tyranny in government which characterised the Roundhead policy; whilst, on the other hand, it is quite obvious to us that, under a continued Roundhead administration, neither the arts nor the sciences could have flourished; culture would have come to an end, and religion become dry and unbeautiful. The Stuart regime, on the other hand, even if it was based upon absurd nonsense concerning "the divine right of kings," and even if it did encourage licentiousness, provided that warm, genial atmosphere in which alone the cultivation of the liberal arts is possible. The Cavalier possessed a sense of beauty that the Roundhead lacked: he had either no religion or else a genial and generous one; and whatever may be urged against the 
Stuarts, we must always remember that it was Charles II who granted the Charter to The Royal Society-an event of supreme importance in the real history of the nation, even if it is not always recognised as such.

Into this century of turmoil and stress, Joseph Glanvill was born. $\mathrm{He}$ was, in the phraseology of his time, "a man of many parts," brilliant, versatile, broad-minded-in a way peculiarly characteristic of his age, since in him very many of the diverse streams of thought of this age seem to meet and combine. He was a staunch Anglican, distrusting Nonconformity because of the narrowness of its creeds; but he had a tremendous admiration for Baxter. He was a sceptic, who believed in God. He was a member of The Royal Society, an experimental philosopher, who believed in witchcraft. These things sound somewhat like paradoxes, and in fact some of those critics who have endeavoured to estimate the value of Glanvill's work have found the last of these seeming paradoxes rather too much for them. As a matter of fact, they are not paradoxes at all, or at any rate they are paradoxes which Glanvill succeeded in resolving ; and we shall find, as we proceed, that his philosophy-that is to say, the sum of his views concerning 
this world and the next-forms a consistent whole.

Joseph Glanvill was born at Plymouth in the year 1636. He was the third son of Nicholas Glanville (Joseph dropped the terminal " $\mathrm{e}$ ") of Halwell, Whitchurch, Devonshire, a descendant of the ancient and honourable AngloNorman family of de Glanville. $\mathrm{He}$ was educated at Oxford, then the stronghold of scholasticism, entering Exeter College in 1652, and graduating B.A. in 1655. He received his M.A. degree in 1658, having moved to Lincoln College two years previously. His tutor at Exeter was Samuel Conant, who appears to have subjected him to a rigid intellectual discipline. To this, no doubt, Glanvill owed not a little of his power of logical argument, which was soon displayed in a brilliant demolition of the philosophy upon which he had been nurtured, but whose arid formalities were intolerable to his broad and penetrative mind.

On leaving Lincoln College, Glanvill was appointed chaplain to Francis Rous, one of Cromwell's Lords and Provost of Eton, and took up his residence with him at Acton, Middlesex. Rous died the next year (1659), and Glanvill returned to Oxford. It is recorded that, in this year, he travelled to Kidderminster 
in order to hear Baxter preach, and if possible to obtain a personal interview with him, which latter project, however, was not accomplished. Glanvill, as we have pointed out, was a great admirer of Baxter, with whom he carried on a considerable correspondence commencing in September, 1661. In 1660, the Rectory of Wimbish, Essex, was bought by his brother Benjamin, a London merchant, and presented to him ; and it is probable that in this year his first marriage took place, the lady of his choice being Mary Stocker.

1661 saw the publication of Glanvill's first work, The Vanity of Dogmatizing : or Confidence in Opinions. Manifested in a Discourse of the Shortness and Uncertainty of our Knowledge, And its Causes; with some Reflexions on Peripateticism; and An Apology for Philosophy, the work to which we have referred above, and with which we shall deal at length in the next chapter. His second work, entitled Lux Orientalis, or an Enquiry into the Opinion of the Eastern Sages, concerning the Procexistence of Souls, Being a Key to unlock the Grand Mysteries of Providence, In relation to mans sin and misery, was published in the next year, and appears to have met with a ready demand. It was a defence of the doctrine of the pre-existence of 
souls as put forward by Henry More, the Cambridge Platonist. The works of More and his school of thought were held in high esteem by Glanvill ; it is recorded that he expressed much regret that he had been educated at Oxford and not at Cambridge, where more liberal thought flourished; and between him and More a friendship came into being which lasted throughout his life, and was one of the dominating factors in it. Towards the end of the year in which Lux Orientalis was published, namely 1662, John Humphrey, Vicar of Frome Selwood, Somerset, was expelled for Nonconformity, and the living was presented to Glanvill by Sir James Thynne.

A man in the seventeenth century who wrote a book like The Vanity of Dogmatizing could hardly expect to live his days in peace free from adverse criticism. Glanvill, in the course of his life, was subjected to a great deal of this, and not a little of his time was necessarily taken up in defending his views, which he did with considerable ability, though he had no love of polemics. His first critic was Thomas White, a Roman Catholic priest, and an able controversialist, who, in 1663, published a work in criticism of The Vanity of Dogmatizing and in defence of scholasticism. Glanvill, owing to a 
severe illness, was unable to reply at the moment, but he did so at the close of $1664,{ }^{1}$ the reply in question being published together with a new and revised edition, purged of some youthful excesses, of The Vanity of Dogmatizing, which he now entitled Scepsis Scientifica : or, Confest Ignorance, the way to Science; in an Essay of the Vanity of Dogmatizing, and Confident Opinion. The book was dedicated to The Royal Society, which less than three years previously had been incorporated by Royal Charter. The work was well received by the Society, and on the proposition of Lord Brereton, Glanvill was elected a member. Preferment in the Church soon followed upon Glanvill's reception of this mark of distinction in philosophy, and in 1666 he received the important appointment of Rector of the Abbey Church, Bath, in which town he resided until the close of his life. In the same year was published his Philosophical Considerations touching the Being of Witches and Witchcraft, which

1 The title-page of the only contemporary edition of the book is dated 1665 , but the Imprimatur is dated October 18th, 1664, and it is clear from the record in Thos. Birch's History of the Royal Society (London, 1766) that the book was in the hands of the Society towards the end of this year. The Scepsis was reprinted in $\mathbf{1 8 8 5}$ under the editorship of John Owen. 
was re-issued in the following year, most of the copies of the previous edition having been destroyed in the Great Fire of London. The work was mainly a criticism of $a$ priori objections to the possibility of witchcraft and of what we should now call psychic phenomena. The belief in witchcraft had in Glanvill's day fallen into disfavour. This was partly the result of a reaction from the excesses of the previous half-century, which had culminated in the abominable activities of Matthew Hopkins, the Witchfinder-General, during the closing years of the reign of Charles I ; but partly it was also, as Glanvill saw, the result of atheism and of a mode of life which found it inconvenient to credit the existence of a spiritual world. Glanvill's work was preliminary to an attempt to demonstrate the reality of spirit by the collection of well-authenticated instances of psychic phenomena, an attempt altogether in harmony with his distrust of the airy speculations of scholasticism and his faith in the new experimental philosophy of The Royal Society. In this work, which appears to have been carried on throughout his life, he had an enthusiastic collaborator in Henry More (who also was a member of The Royal Society). Several other persons of note, to whom we shall refer in a later 
chapter, were interested in the project and rendered assistance towards its fruition. The fourth edition of Glanvill's work on witcheraft, published in 1668, is entitled $A$ Blow at Modern Sadducism In some Philosophical Considerations about Witchcraft, and contains, in addition to the Considerations, two relations of psychic phenomena, and a letter from Glanvill to More entitled $A$ Whip for the Droll, Fiddler to the Atheist : Being Reflections on Drollery and Atheism. But the completed product of Glanvill's and More's researches, the famous Saducismus Triumphatus, in which this earlier work is incorporated, ${ }^{1}$ did not see the light of publication until after Glanvill's death, the first edition appearing in 1681, and further editions following in $1683,1689,1700$, and 1726.

A letter of Glanvill's written in 1667 records that he was then in danger from fanatics in Bath. In his day, as in ours, to proclaim oneself a sceptic was to be regarded by the unthinking as an atheist and an enemy to religion. About this time Glanvill made the acquaintance of a Rev. Robert Crosse, a man of the most

1 For some unknown reason $A$ Whip for the Droll was omitted from the first edition. The second we have not seen. Later editions contain it. 
bigoted opinions and of a vindictive and disputatious disposition, who, in the course of conversation, urged the preposterous proposition that Aristotle had more advantages for gaining knowledge than the whole of the members of The Royal Society or any modern philosophers. In the ensuing argument, he appears to have got the better of Glanvill, who was unprepared; and, turning the discussion on to the subject of the inspiration of the Bible, extracted from Glanvill the statements, "that those Holy Oracles were not written methodically," and "that God was pleased in those Inspirations to apply himself much to the Imagination of the Prophets," accused Glanvill of atheism and attacked him in a number of scurrilous ballads and letters, privately circulated. Glanvill was at last forced to reply, which he did in his Plus Ultra: or, the Progress and Advancement of Knowledge Since the Days of Aristotle. In an Account of some of the most Remarkable late Improvements of

1 See Glanvill's Plus Ultra (London, 1668), pp. 129 and 130. (In our quotations from Glanvill's works, we have followed his capitalisation, spelling and punctuation; but not the very complicated typography, which in the case of certain of the books, involves blackletter type, as well as capitals of various sizes, in addition to the usual roman and italic types.) 
Practical, Useful Learning: To Encourage Philosophical Endeavours. Occasioned By a Conference with one of the Notional Way. This work was published in 1668, and is a splendid defence of the new experimental philosophy, as practised by The Royal Society, and a record of its achievements.

To return, however, to 1667 : in that year Glanvill published a Fast Sermon on the King's Martyrdom. Other sermons followed in 1669 and 1670; one on Catholick Charity in the former of these years, and in the latter, two discourses, one concerning The Way to Happiness: Represented in its Difficulties and Incouragements, whilst the other, entitled Aoyov $\Theta \rho \eta \sigma \kappa \epsilon \iota)^{1}$ was an address to the clergy in defence of reason in the affairs of religion.

Concerning Glanvill as a preacher, Dr. Worthington, who appears never to have quite appreciated him at his true worth, wrote of him in 1668, as "spruce and trim ... with . . . white gloves and handkerchief and periwig (which must now and then be pulled)," and

1 This work was issued, in the first place, anonymously. A second edition appeared in 1671 along with Glanvill's Philosophia Pia. It has a separate title-page (dated 1670), but the pagination is continuous throughout the two works. 
criticised his preaching as "romantick." In point of fact, his sermons were plain and practical, being based largely on his observations of the virtues and vices of mankind, and were free from that excess of abstract doctrinal theorising which so greatly marred the preaching of the majority of his contemporaries.

In the year we have now reached in his life, namely 1670 , may probably be placed Glanvill's marriage to Margaret Selwyn; the date of the death of his first wife is unknown.

The next year he again took up cudgels in defence of The Royal Society, writing two controversial books in reply to a Mr. Henry Stubbe, who had adversely criticised his Plus Ultra. In the same year and in the same cause Glanvill published also Philosophia Pia ; or, a Discourse of the Religious Temper, and Tendencies of the Experimental Philosophy, Which is profest by the Royal Society, together with a new edition of $\Lambda$ oyov $\Theta \rho \eta \sigma \kappa \epsilon \iota$.

In 1672, Glanvill was appointed Chaplain in Ordinary to Charles II, and in this year he exchanged the vicarage of Frome Selwood for the rectory of Streat and Walton in the same

${ }^{1}$ See The Diary and Correspondence of Dr. John Worthington (Chetham Society, Manchester, 1886), vol. ii, part 2, p. 294. 
county. In the following year was first published his An Ernest Invitation to the Sacrament of the Lord's Supper, a work which proved immensely popular, running into as many as ten editions. This was followed in 1676 by a volume of sermons and a work, entitled Essays on Several Important Subjects in Philosophy and Religion, which is largely an abridgement of the most important of his previous books, and may be regarded as containing the sum of his philosophy. The Essays in question are as follows :

1. Against Confidence in Philosophy, and Matters of Speculation.

2. Of Scepticism and Certainty.

3. Modern Improvements of Useful Knowledge.

4. The Usefulness of Real Philosophy to Religion.

5. The Agreement of Reason, and Religion.

6. Against Modern Sadducism in the matter of Witches and Apparitions.

7. Anti-fanatical Religion, and Free Philosophy.

The second and the serenth of these were new, the latter, which is a continuation of Francis Bacon's New Atlantis, being, according to James Crossley, an extract from a longer MS. 
entitled Bensalem, which was never published. The other five essays are revisions of the Scepsis Scientifica, the Plus Ultra, the Philosophia Pia, Aoyov $\Theta \rho \eta \sigma \kappa \epsilon \iota a$, and the work on Witcheraft.

In 1678, Glanvill was installed Prebendary of Worcester. He published this year a work on Preaching (reprinted in 1703), and wrote his The Zealous and Impartial Protestant, which was published posthumously in 1681. Death claimed him whilst he was still but a young man. On 4th November, 1680, he succumbed to a fever, and was buried in the Abbey Church, Bath.

We shall close this account of Glanvill's life by quoting the opinions concerning the man and his work of two of his contemporaries and of one who could view him from the vantage point of time. Anthony à Wood, who knew Glanvill and who appears to have hated him because of his anti-Aristotelianism and his preference for the learning of Cambridge to that of Oxford, wrote in his Athence Oxonienses a spiteful and somewhat perverted account of Glanvill's life ; but even he had to admit that Glanvill "was a person of more than ordinary parts, of a quick, warm, spruce and gay fancy," adding that " he had a very tenacious memory and was a great master of the English language, 
expressing himself therein with easy fluency, and with a manly, yet withall a smooth style." 1

In his Preface to Some Discourses, Sermons and Remains of the Reverend Mr. Joseph Glanvill (London, 1681), Glanvill's friend, Anthony Horneck, wrote of him as follows :

"Death seemed to envy the vast parts of so great a man, and in the ascent of his Age, snatch't him away, when the learned world expected some of his greatest attempts, and enterprises. As he valued no notions, that were mean and trivial, so those he hath sent abroad, savour of a more than ordinary genius. His Soul seemed to be spun of a finer thread than those of other mortals, and things look'd with another face, when they passed through the quicker fire of his Laboratory. ... His Sermons as they were very solid, so they were (which is the grace and life of them) pathetick, and by his zeal and fervour one might guess, how big his desire unto God for Israel was, that they might be saved; Though he met sometimes with disappointments, yet he remembered he was a Christian. And as he was not without his crosses, so he carried himself under them like a true Philosopher."

1 Anthony à Wood: Athence Oxonienses ... new edition with additions ... by Phillip Bliss (London, 1817), vol. iii, col. 1245. 
And, finally, to quote the words of W. E. H. Lecky :

"Joseph Glanvill ... I venture to think, has been surpassed in genius by few of his successors. Among his contemporaries he was especially praised as an able scholar and dialectician, and as a writer whose style, though not untinctured by the pedantry of his age, often furnishes the noblest examples of that glorious eloquence, so rich in varied and majestic harmonies, of which Milton, Sir Thomas Browne and the early Anglican divines were the greatest masters. To us, however, who look upon his career from the vantage ground of experience, it assumes a still higher interest, for it occupies a most important position in the history of that experimental philosophy which has become the great guiding influence of the English mind." 1

Such was Joseph Glanvill : a man whose philosophy was of moment in his own day, and is of interest and value for us still. Of that philosophy, and especially of Glanvill as a forerunner of The Society for Psychical Research, we shall endeavour to deal in the ensuing chapters.

1 W. E. H. Lecky : History of the Rise and Influence of the Spirit of Rationalism in Europe, fourth edition (London, 1870), vol. i, pp. 110 and 111. 


\section{CHAPTER II}

\section{SCEPTICISM}

" THE predominating characteristic of the mind of Glanvill," wrote W. E. H. Lecky, " was an intense scepticism." 1 As we have pointed out, the nature of scepticism has been, and still is, frequently misunderstood. Glanvill, as a sincere and whole-hearted Anglican divine, was, it is hardly necessary to say, very far from being an enemy to religion; he was neither an atheist nor even a materialist; but he was an enemy to dogmatism in both philosophy and theology. He recognised the frailty of human understanding and the futility of the wordy disputations with which both the philosophers and theologians of his day so greatly busied themselves. He was conscious of the tremendous magnitude of the task that presented itself to the mind in its conquest of the Un-

- known, and he realised that this conquest was to be achieved only by the assiduous and patient

$$
1 \text { Op. cit., vol. i, p. } 111 .
$$


enquiry of Nature herself. Moreover, if his mind revolted from the dogmatism which found all wisdom within the covers of Aristotle's works, it revolted no less from that form of dogmatism which, flying to the opposite extreme, denied the possibility of certitude, and in his essay "Of Scepticism and Certainty" he expressly criticised Pyrrho because of the latter tendency. With Glanvill, as with Des Cartes, scepticism was the ground from which the tree of knowledge was to be raised. "He that would rebuild a decayed structure," he wrote, " must first pluck down the former ruines." 1 Like Des Cartes also, he found no occasion to doubt the fundamental principles of Christian divinity, and he deemed certitude also to reside in the demonstrations of mathematics. His scepticism was essentially a species of tolerance; "All Opinions have their Truth," he wrote, " and all have what is not so ; and to say all are true and none, is no absurdity." : In other words, to sum up the nature of his scepticism, Glanvill was thoroughly imbued with what we now call the scientific spirit; and that his Scepsis Scientifica assisted in the demolition of

1 Scepsis Scientifica . . e edited by John Owen (London, 1885), p. 63.

$$
2 \text { Ibid., p. } 57 .
$$


the "decayed structure" of scholasticism, which made possible the rearing of the grand edifice of modern scientific knowledge, can hardly be denied.

The Scepsis Scientifica opens with an account of human ignorance, and of some of the great problems which the human mind had signally failed to solve. Glanvill instances such problems as those of the nature and origin of the soul, its union with the body, and its power of acting therethrough. From metaphysical he passes to a consideration of unsolved psychological, physiological and other problems : the manner of sensation, the nature of the memory and the means whereby animal, vegetable and mineral bodies are formed; and he finds the materialistic hypothesis no less satisfactory than its alternatives. In one particularly fine passage he writes as follows :

"Nor is the composition of our own Bodies the only wonder: we are as much nonplust by the most contemptible Worm, and Plant, we tread on. How is a drop of Dew organiz'd into an Insect? or a lump of Clay into a more perfect Animal ? How are the Glories of the Field spun, and by what Pencil are they limn'd in their unaffected bravery? By whose direction is the nutriment so regularly distributed 
unto the respective parts, and how are they kept to their specifick uniformities? If we attempt Mechanical solutions, we shall never give an account, why the Wood-cock doth not sometimes borrow colours of the Mag-pye ; why the Lilly doth not exchange with the Daysie; or why it is not sometime painted with a blush of the Rose? Can unguided matter keep it self to such exact conformities, as not in the least spot to vary from the species? That divers Limners at a distance without either copy, or designe should draw the same Picture to an undistinguishable exactness, both in form, colour, and features; is more conceivable, then that matter, which is so diversified both in quantity, quality, motion, site, and infinite other circumstances, should frame it self so unerringly according to the Idea of its kind. And though the fury of that Apelles, who threw his Pencil in rage upon the Picture he had essayed to draw, once casually effected those lively representations, which his Art could not describe ; yet 'tis not likely, that one of a thousand such præcipitancies should be crowned with so an unexpected an issue. For though blind matter might reach some elegancies in individual effects; yet specifick conformities can be no unadvised productions, but in greatest likelyhood, are regulated by the immediate efficiency of some knowing agent: which whether it be seminal Formes, according to the Platonical Principles, or whatever else we please to suppose; the 
manner of its working is to us unknown : or if these effects are meerly Mechanical; yet to learn the method of such operations may, and hath indeed been, ingeniously attempted; but I think cannot be performed to the satisfaction of severer examination." 1

Glanvill then turns his attention to the causes of human fallibility ; amongst which he places (1) superficiality, (2) the unreliability of sensedata, upon which all knowledge is necessarily based, (3) fallacies of the imagination, (4) precipitancy and (5) the tendency of man's affections to warp his judgments. Concerning the unreliability of the senses, Glanvill gives a number of instances, some, it is interesting to note, concerned with the relativity of motion, whilst others are cases of the attribution to material bodies of qualities, such as heat, which really exist in us ; though he fails to realise that what is true in this respect of the so-called secondary qualities of matter, is true also of the primary ones-for example, extension. At the end of this section of his book, Glanvill points out that it is not really our senses which

1 Scepsis Scientifica, ed. cited, pp. 39 and 40. Amongst the phenomena dealt with by Glanvill in this section of his work is the once universally accredited one of palingenesy, in which a sort of vaporous ghost of a plant was thought to be obtained from its ashes by chemical means. 
deceive us, but our judgments. He writes as follows :

"And yet to speak properly, and to do our senses right, simply they are not deceived, but only administer an occasion to our forward understandings to deceive themselves: and so though they are some way accessory to our delusion; yet the more principal faculties are the Capital offenders. If the Senses represent the Earth as fixt and immoveable ; they give us the truth of their Sentiments. To sense, it is so, and it would be deceit to present it otherwise. For (as we have shewn) though it do move in it self ; it rests to us, who are carry'd with it. And it must needs be to sense unalterably quiescent, in that our own Rotation prevents the variety of successive Impress; which only renders motion sensible. And so if we erroneously attribute our particular incommunicable sensations to things, which do no more resemble them then the effect doth its æquivocal cause; our senses are not in fault, but our precipitate judgments. We feel such, or such a sentiment within us, and herein is no cheat or misprision : 'tis truly so, and our sense concludes nothing of its Rise or Origine. But if hence our Understandings falsly deduct, that there is the same quality in the external impressor ; 'tis it is criminal, our sense is innocent. When the Ear tingles, we really hear a sound: If we judge it without us, it's the fallacy of our 
Judgments. The apparitions of our frighted Phancies are real sensibles: But if we translate them without the compass of our Brains, and apprehend them as external objects ; it's the unwary rashness of our Understanding deludes us." 1

Glanvill's point is just, and the non-recognition of its truth has led to much confusion of thought.

Amongst the fallacies of the imagination, Glanvill places the alleged opposition between reason and faith. We shall, however, deal at some length with Glanvill's attitude on this subject in the next chapter, and therefore pass on to consider what he has to say concerning the danger of precipitancy. He takes this occasion to urge the needs of research, pointing out that :

"The mind of man being . . naturally amorous of, and impatient for Truth, and yet averse to, and almost incapacitated for that diligent and painful search, which is necessary to its discovery ; it must needs take up short, of what is really so, and please it self in the possession of imaginary appearances, which offering themselves to its embraces in the borrowed attire of that, which the enamour'd Intellect is in pursuit of, our impatient minds

1 Scepsis Scientifica, edition cited, pp. 77 and 78. 
entertain these counterfeits, without the least suspicion of their cousenage." 1

The section of the book devoted to the various ways in which the affections mislead us is particularly interesting, ${ }^{2}$ especially as modern psychology is strongly inclined to the view that the majority of men's beliefs are not rational, but have an instinctive basis. ${ }^{3}$ Glanvill indicates under this heading how men's judgments are perverted by their natural dispositions, by custom and education, by self-interest and the love of their own productions, and finally by the unreasoning homage paid to antiquity and authority. His acumen is extraordinary. $\mathrm{He}$ points out, for instance, that many men profess

1 Scepsis Scientifica, edition cited, p. 95.

2 Cf. Philosophia Pia (London, 1671), p. 45 : " There are few that hold their opinions by Arguments, and dry reasoning, but by congruity to the understanding, and consequently by relish in the affections."

${ }^{3} C f$. W. Trotter: Instincts of the Herd in Peace and War, Second Edition (London, 1919), p. 38 : "It is the belief which is the primary thing, while the explanation, although masquerading as the cause of the belief, as the chain of rational evidence on which the belief is founded, is entirely secondary, and but for the belief would never have been thought of. Such rationalizations are often, in the case of intelligent people, of extreme ingenuity, and may be very misleading unless the true instinctive basis of the given opinion or action is thoroughly understood." 
Christianity merely because they have been educated in a country where this is the official religion, and not because of any rational conviction of its truth. He shows a thorough realisation of the possibility of the mind deceiving itself, writing :

"Self designers are seldome disappointed, for want of the speciousness of a cause to warrant them; in the belief of which, they do oft so really impose upon themselves, as they industriously endeavour it upon others." 1

And against the intolerable deference paid to Aristotle, which had so retarded human enquiry, he raises an irresistible protest. "If we owe it to him [Aristotle]," he writes, "that we know so much ; 'tis perhaps long of his fond adorers that we know so little more." a

Against Aristotelianism, Glanvill then proceeds to direct a number of chapters of his work. Admitting it to be useful as an exercise for university students, he can grant it to have little more utility. He criticises it as merely verbal-asserting that " to wrest names from their known meaning to Senses most alien, and to darken speech by words without knowledge ;

1 Scepsis Scientifica, edition cited, p. 112.

2 Ibid., p. 120. 
are none of the most inconsiderable faults of this Philosophy," 1_as litigious, as giving no account of phenomena, as inept for new discoveries, and as being inconsistent with divinity and itself.

Glanvill then raises the query whether any system of knowledge (or science as he calls it) is possible which shall possess the certitude which the dogmatic schoolmen attributed to their beliefs. In the chapter devoted to this topic, Glanvill has a very important section criticising the concept of causation, in which he undoubtedly anticipates Berkeley and Hume. He writes :

"All Knowledge of Causes is deductive : for we know none by simple intuition; but through the mediation of their effects. So that we cannot conclude, any thing to be the cause of another ; but from its continual accompanying it : for the causality it self is insensible. But now to argue from a concomitancy to a causality, is not infallibly conclusive: Yea in this way lies notorious delusion."

\section{And he concludes that:}

"We may affirm, that things are thus and thus, according to the Principles we have
1 Scepsis Scientifica, ed. cited, p. 134.
2 Ibid., p. 166. 
espoused : But we strangely forget our selves, when we plead a necessity of their being so in Nature, and an Impossibility of their being otherwise." I

To give instances of reputed impossibilities may seem to us to be a strange thing for a sceptic to do. Yet the next chapter in Glanvill's book is devoted to such matters, and a moment's reflection will show us that this is entirely in accordance with the whole spirit of the work. The instances in question are of particular interest, and deal with the power of the imagination, "secret conveyance" (or telepathy, as we should now say) and sympathetic cures. It was as an instance of the power of the imagination that Glanvill related in the earlier edition of the work the story of "The Scholar Gipsy", upon which Matthew Arnold based his fine poem. The story is omitted in the Scepsis Scientifica, Glanvill presumably doubting its accuracy. The powers of the sympathetic wound-salve ${ }^{2}$ we no longer credit; but those of the imagination are in a different category, and the possibility of the interaction of minds apart from

1 Scepsis Scientifica, ed. cited, pp. 170 and 171.

$2 C f$. H. S. Redgrove: "The Powder of Sympathy: A Curious Medical Superstition", Bygone Beliefs (London, 1920). 
the use of bodily sense has in recent years been established beyond cavil.

Towards the end of his book, Glanvill returns to the question of the reliability of sense-data, and points out the possibility that the sensations called by the same name by different percipients may not actually be identical. He seems, however, rather afraid to follow up this critical line of thought, and abandons it as perhaps too speculative. This was, perhaps, wise, for the time was not then ripe for the theory that truth is to be found only in relations and not in facts. ${ }^{1}$

Glanvill has much to say in praise of Des Cartes, who, he writes :

"Intends his Principles but for Hypotheses, and never pretends that things are really or necessarily, as he hath supposed them: but that they may be admitted pertinently to solve the Phænomena, and are convenient supposals for the use of life." ?

Again we are struck by the modernity of Glanvill, and we cannot but greatly admire him forhis pragmatic attitude of mind." Contrasted

1 Cf. H. S. Redgrove: The Magic of Experience (London, 1915), especially § 12.

2 Scepsis Scientifica, edition cited, p. 183.

- Cf. Philosophia Pia (London, 1671), p. 44 : "Certainty 
with Des Cartes are the dogmatists, and Glanvill's final warning against dogmatism contains much salutary advice for all those who would philosophise aright. "Opinionative confdence," he writes, "is the effect of Ignorance" ; it "ever more dwells with untamed passions", ; it "is the great disturber both of our selves and the world without us" ; it is a sign of "ill manners and immodesty"; it "holds the Dogmatist in the chains of Error .... and betrayes a poverty and narrowness of spirit." 1 And with these words of Glanvill's our account of his scepticism may well be brought to an end.

is not in many things; and ... the most valualle knowledge is the practical."

1 Scepsis Scientifica, edition cited, pp. 194-201. 


\section{CHAPTER III}

\section{PLATONISM}

What Platonism meant in the seventeenth century may be gathered from the fact that then the alternative title to Platonist was that of Latitudinarian. On the one hand, the religious world was torn with dissensions concerning doctrinal matters, in many cases of the most trivial nature; whilst on the other hand, and partly as a result of this, a spirit of entire indifference to religion was abroad. Reason was either denied to be valid, or else was prostituted to base ends. The result was turmoil in the world of thought and licentiousness in the world of action. The school of Cambridge Platonism formed, as it were, a haven of rest. Indifferent to mere matters of doctrinal opinion and insisting only upon fundamentals, the Cambridge Platonists held a good life as the essential reality of religion, and, believing in the thorough congruence of reason and revelation, taught that both were equally 
the voice of God. Their indebtedness to Plato was perhaps less than to Plotinus; and by means of a fusion of Neo-Platonic doctrines with those of a broad Protestantism they achieved a school of intellectual mysticism of a quality that has, perhaps, never been surpassed.

Glanvill does not appear to have gone very deeply into the philosophy of Plato and the Neo-Platonists. His Platonism takes the form rather of a devotion to the Platonic methodof a reaction from the aridity which the Schoolmen had made of Aristotle's philosophy and an intense admiration for the works of the subtle and ingenious Henry More. His spirit was entirely that of the Cambridge Platonists, even if it lacked something of the deep philosophical mysticism of the mind of John Smith and of the speculative quality of that of More. A modern author well writes of him as having "the love of intellectual adventure common to all true lovers of the academic philosophy" and "something alike of the genial urbanity and of the visionary poetry of the Phaedrus and the Symposium." 1

The Platonic theme of the perfect congruency

1 Ferris Greenslet, Ph.D.: Joseph Glanvill, a Study in English Thought and Letters of the Seventeenth Century (New York, 1900), p. 122. 
between Reason and the teachings of revealed Religion runs throughout the whole of Glanvill's work. Thus, in the Scepsis Scientifica, the following passage occurs :

"To say, Reason opposeth Faith, is to scandalize both: 'Tis Imagination is the Rebel; Reason contradicts its impious suggestions. Nor is our Reason any more accountable for the Errours of our Opinions ; then our holiness for the immoralities of our Lives: And we may as well say, that the Sun is the cause of the shadow, which is the effect of the intercepting opacity, as either. Reason and Faith are at perfect Unisons: The disharmony is in the

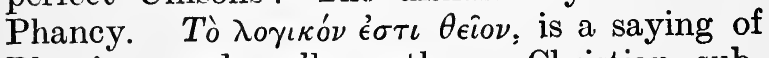
Plato's; and well worthy a Christian subscription, Reason being the Image of the Creator's Wisdom copyed out in the Creature. Though indeed, as 'tis now in the subject, 'tis but an amassment of imaginary conceptions, præjudices, ungrounded opinions, and infinite Impostures ; and 'tis no wonder, if these are at odds with the Principles of our belief : But all this is but apish Sophistry, and to give it a Name so Divine and excellent, is abusive and unjust." 1

In Lux Orientalis we read as follows :

"The Right Reason of a Man, is one of the 1 Edition cited, pp. 87 and 88. 
Divine volums, in which are written the indeleble Idæas of eternal Truth : so that what it dictates, is as much the voice of God, as if in so many words it were clearly exprest in the written Revelations." 1

And there is much to the same effect in his other works, especially the Philosophia Pia and Aoyov $\Theta \rho \eta \sigma \kappa \epsilon \iota a$. The latter work-whose full title is Aoyov $\Theta \rho \eta \sigma \kappa \epsilon \iota a$; or, a Seasonable Recommendation, and Defence of Reason, In the Affairs of Religion; against Infidelity, Scepticism, and Fanaticisms of all sorts - was a visitation sermon expressly devoted to this theme. In it, as also in the Philosophia Pia, Glanvill points out the mischief done to Christianity by the disparagement of reason, how it has undermined faith, given rise to idle contentions (and worse), and encouraged fanaticism; and he takes as his thesis that " reason is very serviceable to Religion; and Religion very friendly to Reason." 2 Religion he defines as being primarily duty, which is " all that which God hath commanded to be done by his Word, or our Reasons." " "Reason," he writes, "is

1 Lux Orientalis (London, 1662), pp. 115 and 116.

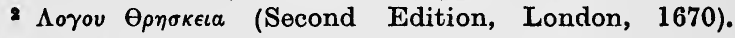
Seo Philosophia Pia (London, 1671), p. 151.

3 Ibid., p. 159. 
certain, and infallible." 1 This, however, is said of "Reason in the object, viz. Those Principles of Truth which are written upon our Souls," " or, as he elsewhere puts it in the same work, of "First Principles, and the Conclusions that are raised from them, and the observations of sense." 3 Such observations, he explains, must be rightly circumstanced, for, as demonstrated at length (as we have seen) in the Scepsis Scientifica, and insisted on again in the present work, the human faculty of understanding is very weak and imperfect, man not always reasoning rightly, but allowing his mind to be swayed by the appetites and lower passions of the soul. Beloved of all the Cambridge Platonists was the passage of Scripture which asserts that "the spirit of man is the candle of the Lord." " This spirit they interpreted as meaning reason. Glanvill quotes the passage in the work we have just mentioned, writing- " Reason is, in a sense, the Word of God, viz. that, which he hath written upon our minds, and hearts ; as Scripture is that, which is written in a Book." "We of the twentieth century, who have learned to value reason

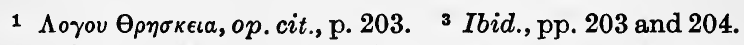

2 Ibid., p. 197. The Proverbs, ch. xx, v. 27. op. cit., p. 205. 
! aright and to give it supreme place, need to recreate for ourselves something of the atmosphere of the seventeenth century in order to realise the real significance of these words of Glanvill's and what a commentary they form on the nature of his mind.

Glanvill's one work dealing with an exclusively Platonic subject was his Lux Orientalis, published anonymously in 1662. The work was dedicated to Francis Willoughby and was, as we have already pointed out, a defence of More's doctrine of the pre-existence of souls. It was reprinted in 1682, together with George Rust's Discourse of Truth and copious annotations by More himself. The controversy as to the origin of the soul is by no means dead, but biological research, especially as concerns heredity, has largely rendered obsolete Glanvill's arguments, which are based partly on the difficulties inherent in the alternative hypotheses of continual creation and traduction, and partly on a priori considerations concerning the nature of God. There are, however, some things in the book which cannot but excite our admiration, and a short account of its contents will be of interest as indicating Glanvill's attitude towards an important question.

The hypothesis of continual creation_is re- 
jected by Glanvill as ill agreeing with the goodness and dignity of the Divine Nature, whilst traduction is rejected because of the opposition between it and his view of the soul as "stable, permanent, and indivisible." 1 For the latter reason he also denies the doctrine, common to so many mystical teachers, that the soul is a particle of the Divine Essence. His positive argument in favour of pre-existence is based upon the notorious diversity of men's characters, those essential differences in their souls which cannot be explained by means of custom, education or peculiarities in their bodily conditions. He urges that pre-existence alone is in agreement with the goodness and equity of God and that "exact Geometrical justice" : which, as a consequence, runs throughout the Universe. Concerning the nature of God he has some fine passages which are worthy of preservation; thus, in one place he writes as follows :

"Whoever conceives rightly of God, apprehendshim to be infinite and immense Goodnesse, who is alwaies shedding abroad of his own exuberant fulnesse: There is no straightness in the Deity, no bounds to the ocean of Love.

1 Lux Orientalis (London, 1662), p. 28.

I Ibid., p. 124. 
Now the divine Goodnesse referrs not to himself, as ours extends not unto him. He acts nothing for any self-accomplishment, being essentially and absolutely compleat and perfect. But the object and term of his goodnesse is his creatures good and happinesse, in their respective capacities." 1

Again, in a passage where the Platonic influence is very marked, he writes :

"The Divine goodnesse, according to the wise direction of the eternal intellect, in like distinct and orderly manner produceth all things : viz. according to all the variety of their respective idæas in the divine wisdome." :

Whilst in another passage, which reminds us of the theory of a Spiritual Sun put forward by Swedenborg many years later, he writes as follows :

"The most congruous apprehension that we can entertain of the Infinite and eternal Deity, is to conceive him as an immense and all glorious Sun, that is continually communicating and sending abroad its beams and brightnesse."'s

The evil of the actual world seems to afford a standing contradiction to the existence of a God of infinite power and infinite love. But

1 Ibid., p. 66.

2 Ibid., p. 88.

3 Ibid., p. 124. 
Glanvill explains this as being due to the "liberty of will to good and evil, which is one of our essential Attributes" ${ }^{1}$; and our incarnation here in the world of matter is envisaged by him as the result of a fall from a nobler condition in a pre-existent state of the soul.

Having, as he thinks, established the superiority of the theory of pre-existence over the two rival hypotheses, Glanvill allows his fancy free play and indulges in an adventuresome speculation (which, it should be noted, he carefully labels as such) concerning the past state of the soul and what the future has in store for it. The soul, he asserts, is incapable of acting otherwise than in a body; but, at the same time, he urges that souls " are capable of living in other bodies besides Terrestrial." " Moreover he suggests that "the soul in every state hath such a body, as is fittest for those faculties and operations that it is most inclined to exercise" " ; and, since the powers and faculties of the soul are of three sorts, namely (i) spiritual and intellectual, (ii) sensitive, and (iii) plastic, so bodies, he argues, are likewise of three sorts, namely ethereal, aerial, and terrestrial, corresponding to these. The spiritual and intellectual powers

1 Lux Orientalis, p. 85.

2 Ibid., p. 131. I Ibid., p. 134. 
and faculties are the highest-they are the powers of contemplation, or the Platonic nous, whereby the soul attains to Divine Truth. The sensitive powers and faculties are those of sensation, whereby the soul is delighted or disgusted with the things of sense; whilst the plastic powers and faculties are those in virtue of which the soul forms and moves the body. In the soul's original or ethereal state of existence all these powers and faculties were in operation, but the two lower were in strict subordination to the spiritual and intellectual. Through their aggrandisement the soul fell, first to an aerial, and afterwards to a terrestrial state of embodiment. Now, in order that matter shall form a suitable body for the soul, it needs a lengthy preparation; so that the majority of fallen souls remain in a disembodied and, consequently, quiescent state until their turn comes to be incarnated through physical birth.

Concerning the fate of man's soul after the death of his body, Glanvill urges that the plastic powers will have become exhausted by their continual exertion in the strenuous battle of earth-life. Some souls will be capable of regaining their ethereal bodies, others will revert to the aerial state, whilst those which have 
refrained from the exercise of the higher faculties and, in place of cultivating morality, have immersed themselves in evil, will be confined, in virtue of their own nature, to a quasimaterial hell, situated in the centre of the earth, which, in accordance with the Cartesian theory, is regarded as being in a state of fiery vapour. The souls of those who die in childhood, however, he imagines will return to the quiescent state, to be reincarnated in material bodies in the course of time; a theory, by the way, which More was unable to accept. ${ }^{1}$ It is, perhaps, curious that Glanvill, whilst accepting the Platonic doctrine of pre-existence, denied, except for this very limited application, the correlative one of metempsychosis. It will, we suspect, be regarded as a serious defect in his philosophy by many speculative thinkers nowadays, and it must be admitted that whatever may be urged for or against the theory of reincarnation, the doctrine of pre-existence loses a great deal of its force when divorced therefrom.

But to conclude this account of Glanvill's speculations concerning the destiny of the soul : he is not destitute of a larger hope for the souls

1 See his Annotations in the 1682 edition of the work, pp. 126-128. 


\section{PLATONISM}

confined in hell; but suggests that, at the end of the age, the fire within the earth will burst forth and consume the whole world. This will be in the nature of a purification, and, out of the conflagration of the old world, a new and better world shall arise, and the souls hitherto confined in hell, purified by their sufferings, shall regain something of their lost estate.

The whole of this speculation, we are afraid, is highly fanciful and of little practical utility to thought. But there are times, perhaps, when many of us envy the men of the seventeenth century, to whom intellectual adventures such as these were possible; and it is, perhaps, permissible to place an artistic value upon them even when, for us, their measure of truth has become void. 


\section{CHAPTER IV}

\section{THE ROYAL SOCIETY}

As far back as the thirteenth century, Roger Bacon formulated the elements of scientific method, attacking the all-powerful scholasticism of his day and emphasising the necessity of the experimental observation of Nature and the utility of mathematics as an instrument of thought. ${ }^{1}$ Roger Bacon, however, was born before his time: Francis Bacon was more fortunate, and shortly after his death, which occurred in 1626, and as a direct result of his labours, began to be realised his dream of a College of Philosophers devoted to the inductive method and the experimental investigation of Nature. Francis Bacon, unlike his forerunner Roger, undervalued mathematics, an error which, if persisted in by the new philosophy, would have proved fatal. René Des Cartes (1596-1650), however, corrected it ; and on the

1 See H. S. Redgrove: Roger Bacon, the Father of Experimental Science, and Mediceval Occultism (London, 1920). 
joint basis of Baconism and Cartesianism the giant structure of modern science and modern philosophy has been laboriously erected.

The origin of The Royal Society, which represented the new movement in philosophy in Britain, may be traced back to the year 1645 , when there began to be held, either at Gresham College, or elsewhere in London, meetings of a number of philosophers ambitious to put into practice the Baconian method. About 1648 or 1649 the company was divided, one section meeting in Oxford, the other section continuing to meet in London as before. Amongst the Oxford members of this informal association was the Hon. Robert Boyle, at whose lodgings the assemblies were sometimes held. He was a man of the greatest eminence in his day : it was he who laid the foundations of the modern science of chemistry as distinct from alchemy and iatro-chemistry ${ }^{1}$; and his name will live for ever in connection with his investigation of the behaviour of gases under pressure and the law which he was thereby led to formulate.

In 1659 the majority of the members of the

1 The central doctrine of iatro-chemistry was that the object of the science is the preparation of pure medicines and the discovery of new ones. It persisted along with alchemy from the time of Paracelsus (1493-1541) to that of Boyle. 
Oxford section of the Society came to London, and meetings were held, usually at Gresham College, until later in the year this became impossible owing to the fact that soldiers were quartered in the place of meeting. With the Restoration the meetings were revived, and on 28th November, 1660, steps were taken to organise the Society into a more definite form. It was decided to hold regular weekly meetings, and a provisional list of members was drawn up. Not long after, namely on 15th July, 1662, the Society was incorporated by Royal Charter. To give a list of the names of the eminent men its early membership included would be tedious ; but, in addition to Robert Boyle, particular mention may be made of Viscount Brouncker, Sir Kenelm Digby, Sir John Evelyn, Dr. Wallis and Christopher Wren. The energy of the Society was inexhaustible, and it is a great pleasure to read the early volumes of its Transactions (which were first published in 1665) and thereby to absorb something of the enthusiasm and delight of these men who had, as it were, just discovered Nature. The modern thinker who sneers at the seventeenth century members of The Royal Society because they busied themselves about the "sympathetic powder," for which was claimed that it would 
cure wounds by being applied to the weapon, ${ }^{1}$ and because they performed the experiment of forming a circle with the powder of (supposed) unicorn's horn and placing a spider in the centre to see if it would, contrary to current belief, run out-which, by the way, it several times did, - betrays his ignorance of the nature of Science. Such supposititious marvels seemed no more inexplicable and marvellous-nay, rather less - than did innumerable facts of Nature which the early members of The Royal Society discovered and which are now the commonplaces of scientific knowledge. It is by experiment and not by $a$ priori arguments that superstition can be exploded and truth attained; and all honour is due to these seventeenth century men of science that this was the method they adopted.

Glanvill was elected a Fellow of The Royal Society on 14th December, 1664; and in 1670 was appointed Secretary of a local philosophical organisation in Somersetshire affiliated to the Society. Three communications from him are published in the Society's Transactions.

1 Seo Thomas Birch : The History of The Royal Society of London for Improving of Natural Knowledge . . . vol. i, (London, 1766), p. 31.

- See Philosophical Transactions : Giving some Accompt of the Present Undertakings, Studies, and Labours of the 
The first and last are replies to queries concerning the Mendip Lead Mines, the second one contains an account of the Springs at Bath. It may be of interest to note that one of the queries aforesaid was whether the divining rod was employed in locating the ore; which Glanvill found not to be the case, at any rate as far as the experienced workmen were concerned. Also, we note, he reports that he has no record of anybody having seen a "subterraneous Daemon." The paper concerning the Bath Springs is a very adequate account, and Glanvill shrewdly suggests that, in the past, the discovery of such springs and their improvement by art may have been made the occasion for claiming magical powers.

It was not, however, as an experimental philosopher, but as a defender of experimental philosophy, that Glanvill's great service to The Royal Society was rendered. Scholasticism, religious bigotry, superstition and prejudice conspired together to defeat the conquest of Nature by the mind of man. But experimental philosophy had a doughty champion in Glanvill, and modern science owes much to him for having

Ingenious in many considerable parts of the World, vol. ii, (London, 1667), p. 526; vol. iii, (1668), p. 767; and vol. iv, (1669), p. 977. 


\section{THE ROYAL SOCIETY}

so adequately protected it in the days of its infancy. Amongst the several works he wrote with this object, the Plus Ultra must be mentioned as especially admirable; and it is pleasing to note that it gained from the members of The Royal Society the appreciation which was its due. ${ }^{1}$

The book opens with an introductory chapter dealing with the advantages of the experimental method over the old speculative way, in which Glanvill writes of the-

"Designs [of The Royal Society] of making Knowledge Practical, and accomodating Mankind in things of Universal Benefit, by searching into the Creatures of God as they are in his World, and not criticising upon the Images of them as they lye in that which the Phansies of Men have contriv'd." \&

Moreover, he points out that :

"Modern Experimenters think, That the

1 Amongst Evelyn's correspondence there is an interesting letter from him to Glanvill, in which his keen appreciation of the book is expressed. See Memoirs Illustrative of the Life and Writings of John Evelyn, Esq., F.R.S., comprising his Diary ... and Private Correspondence. Edited by William Bray (London, 1818), vol. ii, pp. 233 and 234.

2 Plus Ultra (London, 1668), p. 5. 
Philosophers of elder Times, though their Wits were excellent, yet the way they took was not like to bring much advantage to Knowledge, or any of the Uses of humane Life ; being for the most part that of Notion and Dispute, which still runs round in a Labyrinth of Talk, but advanceth nothing. And the unfruitfulness of those Methods of Science, which in so many Centuries never brought the World so much practical, beneficial Knowledge, as would help towards the Cure of a Cut finger, is a palpable Argument, That they were fundamental Mistakes, and that the Way was not right.

"For, as my Lord Bacon observes well, Philosophy, as well as Faith, must be shewn by its works." 1

The body of the book is devoted to a very excellent account of the advances, since the time of the ancients, in the various departments of scientific knowledge. Amongst these are instanced Napier's discovery of logarithms, Des Cartes' invention of analytical geometry, as well as other advances in mathematical science ; the revolutionary discoveries that had been made in astronomy, and which had shifted the centre of the physical universe from the earth to the sun; advances in geographical knowledge, including the discovery of America; the many

1 Plus Ultra, pp. 7 and 8. 
discoveries and improvements which had been made in natural history; and, finally, the invention of the telescope, microscope, thermometer, barometer, and air-pump. In such pieces of scientific apparatus as those just mentioned, Glanvill sees the means of remedying the shortcomings of men's senses. ${ }^{1}$ His spirit is entirely that of modern science, and he writes always with understanding. In particular may be mentioned, as an instance of this, his suggestion (afterwards to be proved sound) that the Torricellian vacuum, that is, the space above the mercury in a mercurybarometer, is not an absolute void.

From improvements in learning and in the means of research, Glanvill passes to a consideration of inventions and discoveries that had facilitated the dissemination of learning, such as the art of printing and the discovery of the mariner's compass; and he proceeds to a eulogy of The Royal Society and, in particular, of the researches of Boyle, for whom his admiration is almost unbounded. The critics of the Society, he writes :

"Consider not the Design is laid as low as the profoundest Depths of Nature, and reacheth as 
high as the uppermost Story of the Universe ; That it extends to all the Varieties of the great World, and aims at the benefit of universal Mankind. For could they expect that such mighty Projects as these should ripen in a moment? Can a Cedar shoot up out of the Earth like a blade of Grass ? or an Elephant grow to the vastness of his bulk, as soon as a little Insect can be form'd of a drop of Dew ?

"No; The true knowledge of general Nature, like Nature it self in its noblest composures, must proceed slowly, by degrees almost insensible: and what one Age can do in so immense an Undertaking as that, wherein all the generations of Men are concerned, can be little more than to remove the Rubbish, lay in Materials, and put things in order for the Building. Our work is to overcome prejudices, to throw aside what is useless, and yields no advantage for Knowledge or for Life ; To Perswade men that there is worthier Imployment for them, than tying knots in bulrushes ; and that they may be better accomodated in a well-built House, than in a Castle in the Air. We must seek and gather, observe and examine, and lay up in Bank for the Ages that come after. This is the business of the Experimental Philosophers ; and in these Designs a progress hath been made sufficient to satisfie sober expectations: But for those that look they should give them the Great Elixir, the Perpetual Motion, the way to make Glass malleable, and 


\section{THE ROYAL SOCIETY}

Man immortal ; or they will object that the Philosophers have done nothing: for such, I say, their impertinent Taunts are no more to be regarded, than the little chat of Ideots and Children." 1

The book closes with a digression in which Glanvill answers the foolish charge of atheism, a subject which he deals with more fully in his Philosophia Pia.

In this latter work he maintains a fourfold thesis, namely :

“(I) That God is to be praised for his Works.

"(II) That his Works are to be studied by those that would praise him for them.

"(III) That the study of Nature, and Gods Works, is very serviceable to Religion.

"(IV) That the Ministers and Professors of Religion ought not to discourage, but promote the knowledge of Nature and the Works of it's Author." ?

In a passage of rare mystical beauty, he writes that :

"The knowledge of God's Works promotes the end of Religion . . . by keeping the soul under

1 Plus Ultra, pp. 90-92.

2 Philosophia Pia(London, 1671), p. 4. 


\section{JOSEPH GLANVILL}

a continual sense of God. He that converseth with his works, finds in all things the clear stamps of infinite benignity and wisdom; he perceives the divine art in all the turnings, and varieties of nature, and divine goodness in that. He observes God in the colour of every flower, in every fibre of a plant, in every limb of an insect, in every drop of dew." 1

Experimental philosophy, Glanvill urges, is the best antidote to the five enemies to religion -atheism, sadducism, superstition, enthusiasm, and the humour of disputing. As concerns atheism, he finds the mechanical philosophy especially serviceable, as revealing most clearly the hidden beauty and harmonious contrivances of Nature ; and, commenting upon the words of the Psalmist :

"The heavens declare the glory of God ; And the firmament sheweth his handiwork," 2

he remarks tha't, " the plebeian and obvious world no doułst doth, but the Philosophical much more." s

Glanvill's views regarding sadducism we

1 Philosophia Pia, p. 15.

2 Psalm xix, v. 1.

2 Philosophia Pia, p. 21. 
shall deal with in the next chapter. Superstition, it is interesting to note, he defines as the "fond over-value of things in which there is no good and panick fear of those, in which there is no hurt." 1 Amongst the latter, such phenomena as thunder, eclipses, earthquakes, comets, etc., are included, all of which Glanvill, agreeing with modern science, ascribes to natural causes. Augury he ridicules, though he does not deny every kind of presage. Moreover, he points out that philosophy " by making the mind great" frees it "from little scrupulosities about things indifferent," " which may be taken as his comment on certain of the tenets of Nonconformity.

Enthusiasm-that great bugbear of the Cambridge Platonists-Glanvill defines as a "false conceit of inspiration" 3 arising from "excesses, and diseases of Imagination," and manifesting itself in a disparagement of "Sober Reason" and an acceptance of fantastic ideas. Amongst other cases of enthusiasm, we find mentioned by him that of a Warwickshire woman who, like Joanna Southcott many years after, believed herself to be the "Mother of God, and of all things living," "although, apart
1 Ibid., p. 41.
8 Ibid., pp. 56 and 57.
I Ibid., p. 45 .
- Ibid., p. 62. 
from matters of religion, she appeared to be a person of good sense.

As concerns the spirit of disputation, Glanvill writes that:

"Philosophy gives us a sight of the causes of our intellectual diversities, and so takes us off from expecting an agreement in our apprehensions; whereby it discovers the unreasonableness of making harmony in opinion, the condition of Charity and Union; and of being angry, and dividing upon every difference of judgment ; and hereby the hurtful malignities of disputes are qualified, and the disease it self is undermined." 1

And finally, passing to the fourth head, he appeals to his fellow ministers of religion to encourage the study of the new philosophy, and ends the book with a section devoted to answering objections to philosophy.

Such, in brief, was the contribution of Glanvill to the battle in which the new philosophy conquered the old; and we cannot, perhaps, close this chapter better than by quoting from one of his works a magnificent passage in which is portrayed the character of the genuine experimental philosopher:

1 Philosophia Pia, pp. 91 and 92. 


\section{THE ROYAL SOCIETY}

"So that the Philosopher thinks much, and examines many things, separates the Certainties from the Plausibilities, that which is presumed from that which is prov'd, the Images of Sense, Phansie, and Education, from the Dictates of genuine and impartial Reason. Thus he doth before he Assents or Denies ; and then he takes with him also a Sense of his own Fallibility and Defects, and never concludes but upon resolution to alter his mind upon contrary evidence. Thus he conceives warily, and he speaks with as much caution and reserve, in the humble Forms of 'So I think, and In my opinion, and Perhaps 'tis so' -with great difference to opposite Perswasion, candour to dissenters, and calmness in contradictions, with readiness, and desire to learn, and great delight in the Discoveries of Truth, and Detections of his own Mistakes. When he argues he gives his Reasons without passion, and shines without flaming, discourses without wrangling, and differs without dividing. He catcheth not at the Infirmities of his Opposite, but lays hold of his Strength, and weighs the substance without blowing the dust in his eyes. He entertains what he finds reasonable, and suspends his judgment when he doth not clearly understand. This is the Spirit with which men are inspired by the Philosophy I recommend. It makes them so just, as to allow that liberty of judgment to others which themselves desire, and so prevents all imperious Dictates and Imposings, all 
captious Quarrels and Notional Wars. And that this is the Philosophick Genius, may be shewn in a grand Instance, the Royal SocIETY, which is the Great Body of Practical Philosophers." 1

1 Plus Ultra, pp. 146-148. 


\section{CHAPTER V}

PSYCHICAL RESEARCH : PRELIMINARY CONSIDERATIONS

THOSE critics who have found something inconsistent in the fact that Glanvill, the author of the Scepsis Scientifica, the supporter of experimental philosophy and defender of The Royal Society, undertook an investigation of the question of the reality of witcheraft and other psychic phenomena and found the evidence convincing, have, so it seems to us, failed really to comprehend the nature and spirit of scientific method. This is not remarkable. Science sets before us an ideal of incomparable loftiness and demands for its attainment a degree of disinterestedness which it is hard for mankind to achieve. In the history of science it is found that the actual and the ideal do not, by any means, always coincide. Almost throughout the eighteenth and nineteenth centuries the minds of workers in science were clouded by materialistic metaphysics. To-day, perhaps, 
our sight is clearer, and it is being recognised that the problems of the supernatural must be approached as are those of the natural, i.e. experimentally and without $a$ priori bias.

It was because Glanvill was a whole-hearted believer in the new experimental philosophy, because he was so thoroughly imbued with the scientific spirit, that he saw that the question of witchcraft was one to be settled, not by argument, but by the evidence of fact. Moreover, a far more important question was involved: a demonstration of the reality of witchcraft meant a proof of the reality of spirit, and, hence, would provide weighty evidence in favour of the Christian doctrine of immortality. On the other hand, he realised that it was just because of what it involved that the belief in witchcraft was, in many cases, so hotly combated, and he saw that, as concerned many of the incredulous, a priori objections (however illogical) had to be answered, and the probability of the existence of spiritual beings established a priori, before any de facto evidence would be tolerated. The Considerations about Witchcraft was the result. The work is of more than historical interest, because, although a good deal of the argument is obsolete, objectors to spiritualism (in the widest sense of the term) 
having shifted their ground during the last two hundred years, some of the objections Glanvill had to meet are with us still to-day.

In accordance with the views expressed in Lux Orientalis, Glanvill, in the Considerations about Witchcraft, suggests that there may be several grades of spirits, inhabitants of the air, the ether and the world of pure thought. $\mathrm{He}$ writes :

"Were there no order of Beings between Us, who are so deeply plung'd in the grossest Matter, and pure unbodied Spirits, 'twere a mighty jump in Nature. Since then the greatest part of the World consists of the finer Portions of Matter, and our own Souls are immediately united unto these, 'tis infinitely probable to conjecture, that the nearer Orders of Spirits are vitally joyn'd to such Bodies; and so Nature by degrees ascending still by the more refined and subtle Matter, gets at last to the pure Nóes, or immaterial Minds, which the Platonists made the highest Order of created Beings." 1

The spirits of the lowest grade, presumably, are those responsible for the majority, at any

1 "Some Considerations about Witcheraft." See Saducismus Triumphatus. . . . Third Edition with Additions (London, 1700), Part 1, p. 23. 
rate, of psychic phenomena. The Devil, Glanvill points out, need not always be invoked in explanation; thus, the "familiar" of a witch, he suggests, may be " some departed humane Spirit, forsaken of God and goodness, and swallowed up by the unsatiable desire of mischief and revenge." 1 Nor does he deny the possibility of good spirits playing a part in the affairs of this life, " since, if we judge by the Analogy of the natural World, all things we see are carried on by the Ministry of second Causes, and intermediate Agents." He continues, in a passage reminiscent of the views of the late Alfred Russel Wallace:

"And it doth not seem so magnificent and becoming an apprehension of the Supream Numen, to fancy his immediate Hand in every trivial Management. But 'tis exceeding likely to conjecture, that much of the Government of us, and our Affairs, is committed to the better Spirits, with a due subornation and subserviency to the Will of the chief Rector of the Universe. And 'tis not absurd to believe, that there is a Government runs from highest to lowest, the better and more perfect Orders of Being still ruling the inferiour and less perfect."”

1 Saducismus Triumphatus, Part 1, ed. cited, p. 11.

2 Ibid., p. 25. 
Concerning the operations of spirits, Glanvill, in another passage-not, perhaps, altogether in harmony with the one we have just quotedapproaches very near to the modern concept of a " medium" ; and that the warning which his words imply is justified, those who have impartially investigated the phenomena of "automatism" will assuredly agree. $\mathrm{He}$ writes :

"It is most probable, that Spirits Act not upon Bodies immediately, and by their naked Essence, but by means proportionate, and suitable Instruments that they use; upon which account likely 'tis so strictly required, that the Sorceress should believe, that so her Imagination might be more at the Devotion of the mischievous Agent." 1

Such, in brief, are some of the more interesting of Glanvill's speculations about spirits. But no one realised better than he the difficulty of theorising aright and the dangers of dogmatism. Many things might be established by observation and experiment that could not-at the moment, at any rate-be explained. If the seeming incomprehensibility and absurdity of many of the phenomena of witchcraft was urged

1 Ibid., p. 18. 
against their reality-as to-day is the case concerning spiritualism-Glanvill replied :

"Matters of Fact well proved ought not to be denied, because we cannot conceive how they can be perform'd. Nor is it a reasonable method of inference, first to presume the thing impossible, and thence to conclude that the fact cannot be proved. On the contrary, we should judge of the Action by the evidence, and not the evidence by the measures of our Fancies about the Action." 1

"Well proved"-how much argument has hinged upon the significance of these or similar words! Glanvill, it is important to note, was well aware of the prevalency of fraud in the region of psychic phenomena ; but to attribute every case to fraud because some cases had been explained thereby was an argument his logical mind could not tolerate:

"Frequency of deceit and fallacy will warrant a greater care and caution in examining; and scrupulosity and shiness of assent to things wherein Fraud hath been practised, or may in the least degree be suspected: But to conclude, because that an old Womans Fancy abused her, or some Knavish fellows put Tricks upon the

1 Sad. Trium., ed. cited, Part 1, pp. 7 and 8. 


\section{PSYCHICAL RESEARCH}

Ignorant and timorous; that therefore whole Assizes have been a thousand times deceived in Judgments upon matters of Fact, and numbers of sober Persons have been forsworn in things wherein Perjury could not advantage them; I say, such Inferences are as void of Reason, as they are of Charity and good Manners." 1

In his work of collecting well-authenticated cases of psychic phenomena with a view to publication, Glanvill, as we have already pointed out, had the hearty co-operation of Henry More. Of the other persons who were interested in the scheme and took a hand in it, mention must be made of the illustrious Robert Boyle. In a letter to Glanvill, dated 18th September, 1677, Boyle emphasised the necessity of admitting to the collection only relations whose "main circumstances," at least, were " impartially delivered," and verified by personal knowledge, "or by the judicial records, or other competent vouchers." \& $\mathrm{He}$ expressed his keen approbation of the project, and, later (10th February, 1678), sent Glanvill "the authentick account" 3 of a case of witch-

1 Ibid., p. 19.

2 The Works of the Honourable Robert Boyle (London, 1744), vol. v, p. 244.

Ibid., p. 245. 
craft tried in Munster. Mention in this connection must also be made of Anne, Viscountess Conway, More's " heroine pupil," whose seat at Ragley was a centre of philosophic enquiry and a meeting-place for several curious thinkers interested in matters psychic, including More himself, Lady Conway's physician, Francis Mercurius van Helmont (1618-1699), and (in the early part of 1666) Valentine Greatraks (1629-1683), the Irish healer. The latter was something of a thaumaturgist himself, claiming to cure scrofula and other diseases by means of " stroking," or what a later school of thought would have called " magnetic passes." There is considerable evidence as to the authenticity of many of his cures ${ }^{1}$ : but he failed to heal Lady Conway of the disease which continually affected her with headache and ultimately (in 1679) caused her death. F. M. van Helmont was the son of Jean Baptist van Helmont (1577-1644), an alchemist who made many useful chemical discoveries and claimed to have accomplished the transmutation of base metal into gold. The younger van Helmont appears

1 An interesting letter dealing with this man, and testifying to his powers, by Dr. Rust, Dean of Connor and afterwards Bishop of Dromore, will be found in $\S \mathbf{x x}$ of Glanvill's Considerations about Witchcraft. 


\section{PSYCHICAL RESEARCH}

to have been clever, but superstitious; he believed in metempsychosis, and attended the meetings of the Quakers. More suspected him of " enthusiasm." Lady Conway herself was a woman who would have been remarkable in any age for her interest in and mastery of metaphysics, and her mental powers were held in high esteem by Leibniz. Her ultimate conversion to Quakerism was a great blow to her tutor.

The Saducismus Triumphatus - containing the sum of Glanvill's work concerning witchcraft and allied phenomena-was, as we have pointed out, not published until the year after his death. W. E. H. Lecky calls it " probably the ablest book ever published in defence of the superstition." 1 The book is divided into two separately paged parts, ${ }^{2}$ and is prefaced by a separately paged letter with a long postscript by More, polemical in style and dealing mainly with the question of witchcraft in the Bible. The first part contains Glanvill's Considerations, with which we have already dealt. To this is appended two separately paged essays by

1 Op. cit., vol. i, p. 115.

2 The book underwent some augmentation in the course of its various editions. Our description refers to the "Third Edition with Additions" (London, 1700). 
More. The first of these, entitled The Easie, True, and Genuine Notion, and consistent Explication of the Nature of a Spirit, is a translation of most of the last two chapters of More's Enchiridon Metaphysicum. The second is $A n$ Answer to a Letter of a Learned Psychopyrist, Concerning the true Notion of a Spirit, Exhibited in the foregoing Discourse. In these two essays, More maintains his notion of a spirit (which was accepted by Glanvill) as an "Immaterial substance intrinsecally endued with Life and the faculty of Motion" 1-an immaterial substance being defined as one that is indiscerpible and penetrable,--against those whom he calls the Nullibists, Holenmerians and Psychopyrists. The first were the followers of Des Cartes, who denied that spirit was extended. Spirit, therefore, on this view, was nowhere; which seemed to More tantamount to saying that it did not exist. The second were those who held the Augustinian theory and maintained that the spirit was totally in the whole of the body it animated and totally in every part thereof; whilst the last were those who likened spirit to fire and who found the characteristics distinguishing it from matter to be activity, appetite and perception. More's concept of spirit as an

1 The Easie, True, etc., op. cit., p. 26. 


\section{PSYCHICAL RESEARCH}

oxtended substance involved certain difficulties, which, it is interesting to note in view of recent philosophic speculations, he endeavoured to overcome by assuming spirit to be extended in four dimensions. The impenetrability of matter, however, is no longer an article of faith in physics, and the phenomena of the dissociation of personality throw grave doubts on the indiscerpibility of spirit; so that in spite of the seemingly satisfactory logical character of More's notion of spirit, it could nowadays hardly be defended as either easy, true, or genuine. Indeed, in comparing the works of Glanvill and More, one is conscious of a pragmatic quality and consequent value attaching to the former, which the over-ingenious speculations of the latter lack; and most certainly Glanvill was far better qualified than his friend for psychical research. He had the element of worldly wisdom, necessary in addition to philosophic acumen. More lived a too-retired life to be conscious of that dishonesty in other persons from which he was happily free himself.

The second part of the Saducismus Triumphatus consists of a very interesting "Introduction" by Glanvill, followed by an essay by him dealing with biblical evidence for apparitions, spirits and witches, and finally by his 
"Collection of Modern Relations." In addition there are three separately paged appendices, namely, $A$ Continuation of the Collection by More, Glanvill's $A$ Whip for the Droll, which contains some further particulars concerning the first case given in his "Collection", and a translation by Anthony Horneck, from the High Dutch, of an account of contemporary cases of witchcraft in Sweden.

In his Introduction, Glanvill succinctly states the concessions that he is willing to allow to the opponents of the belief in witchcraft, and the postulates to which he demands their assent. The two sections dealing with these matters are worthy of quotation almost in their entirety. He writes:

"I Shall let the Patrons of Witches know what I allow and grant to them ;

" First, I grant, That there are some Witty and Ingenious Men of the opposite Belief to me in the Question. Yea, it is accounted a piece of Wit to laugh at the Belief of Witches as silly Credulity. . . .

"Secondly, I own that some of those who deny Witches have no design against, nor a disinclination to Religion. . . .

"Thirdly, I allow that the great Body of Mankind is very credulous, and in this matter so, that they do believe vain impossible things 
in relation to it. That carnal Copulation with the Devil, and real Transmutation of Men and Women into other Creatures are such. That people are apt to impute the extraordinaries of Art, or Nature to Witchcraft, and that their Credulity is often abused by subtle and designed Knaves through these. That there are Ten thousand silly lying Stories of Witchcraft and Apparitions among the vulgar. . . .

"Fourthly, I grant that Melancholy and Imagination have very great force, and can beget strange persuasions. And that many Stories of Witchcraft and Apparitions have been but Melancholy fancies.

"Fifthly, I know and yield, that there are many strange natural Diseases that have odd Symptomes, and produce wonderful and astonishing effects beyond the usual course of Nature, and that such are sometimes falsly ascribed to Witcheraft.

"Sixthly, I own, the Popish Inquisitours, and other Witch-finders have done much wrong, that they have destroyed innocent persons for Witches, and that watching and Torture have extorted extraordinary Confessions from some that were not guilty.

"Seventhly and Lastly, I grant the Transactions of Spirits with Witches, which we affirm to be true and certain, are many of them very strange and uncouth, and that we can scarce give any account of the Reasons of them, or well reconcile many of those passages to the 
commonly received Notion of Spirits, and the State of the next World. . . .

"The demands that I make are ; First, That whether Witches are or are not, is a question of Fact. . . .

Secondly, That matter of Fact can only be proved by immediate Sense, or the Testimony of others Divine or Humane. To endeavour to demonstrate Fact by abstract reasoning and speculation, is, as if a Man should prove that Julius Cesar founded the Empire of Rome, by Algebra or Metaphysicks. . . .

"Thirdly, That the History of the Scripture is not all Allegory, but generally hath a plain literal and obvious meaning.

"Fourthly, That some Humane Testimonies are credible and certain, viz. They may be so circumstantiated as to leave no reason of doubt. For our senses sometimes report truth, and all Mankind are [not] Liars, Cheats, and Knaves, at least they are not all Liars, when they have no Interest to be so.

"Fifthly, That which is sufficiently and undeniably proved, ought not to be denied, because we know not how it can be, that is, because there are difficulties in the conceiving of it. Otherwise Sense and Knowledge is gone as well as Faith. For the Modus of most things is unknown, and the most obvious in Nature have inextricable difficulties in the Speculation of them, as I have shewn in my Scepsis Scientifica. "Sixthly and lastly, we are much in the dark, 
as to the Nature and Kinds of Spirits, and the particular condition of the other World." 1

A more satisfactory basis of investigation than this would be difficult to frame. With the results Glanvill obtained in his search for " matters of fact" concerning witchcraft and spirits we shall deal in the ensuing chapter.

1 Saducismus Triumphatus, edition cited, Part 2, pp. 5-8. 


\section{CHAPTER VI}

PSYCHICAL RESEARCH : FACTS AND THEORIES

THE work of obtaining and verifying the many accounts of psychic phenomena recorded in the Saducismus Triumphatus, under the title of "The Collection of Relations," was very considerable. As Glanvill wrote to Boyle in a letter dated 7th October 1677 :

"I am very careful to inform myself of all particulars of those stories I use, to prevent cavils; and that occasions many letters and enquiries, which have much retarded my business : but I make what haste I safely can, and take care not to make too much." 1

The most interesting and impressive of these relations is undoubtedly the first, the acccount of the so-called "Daemon of Tedworth." This record is concerned with psychic happenings, of the type now known as poltergeist phenomena, occurring in the house of a Mr. John Mompesson

1 The Works of the Honourable Robert Boyle (London, 1744), vol. v, p. 628. 
of Tedworth, Wiltshire. The phenomena, which commenced in April, 1661, ${ }^{1}$ and appear to have continued intermittently until April 1663 (it is not clear that they then ceased), took the form mainly of noises and the capricious movement of objects without any apparent physical cause. They seem to have been characterised (as is usual in poltergeist hauntings) by a spirit of mischief rather than one of maliciousness. Amongst the various types of noises recorded were knockings, bangings, scratchings, the sound of rustling silk, and particularly that of the beating of a drum. The drum in question ${ }^{2}$ was one which had been confiscated from a vagrant drummer who, by means of a forged pass, had in the previous March endeavoured to obtain money from the

1 Two or three details concerning the matter which are omitted by Glanvill will be found in the report of the case published in Mercurius Publicus. Comprising the Sum of all Affairs now in agitation in England, Scotland, and Ireland. . . From Thursday, April 16th, to Thursday, April 23rd, 1663; and The Kingdoms Intelligencer of The Affairs now in Agitation in England, Scotland, and Ireland. ... From Monday, April 20th, to Monday, April 27th, 1663. According to this report it would appear that the phenomena commenced in 1662 , not 1661 , as stated by Glanvill.

2 It should be noted, however, that the drumming was said by Mr. Mompesson to have continued after this drum, on which it appears first to have occurred, was burnt. 
constable of the neighbouring town of Ludgershall, and had been exposed by Mr. Mompesson. The fellow, whose name was William Drury, was, towards the end of 1662, arrested for stealing, and sentenced to deportation, but managed to escape, in April 1663, from the barge in which he was being conveyed. Whilst in gaol he was reported to have accused himself of being the cause of the disturbances at Tedworth, which fact came to the knowledge of Mr. Mompesson, who, learning that Drury had returned to his native village (Uscut, Wilts.), caused him, a few days after his escape, to be apprehended for witchcraft. According to a letter from Mr. Mompesson, printed in Saducismus Triumphatus, we learn that, whilst the Grand Jury found a true bill, the Petty Jury acquitted Drury; and his actual connection with the affair (apart from the supposed confession) appears to have been very slight.

The whole question of poltergeist phenomena is one of extraordinary difficulty. Mundane explanations, such as rats, water-pipes, the settling of a house on its foundations, and pranks played by mischievous persons at once suggest themselves. But, whilst they can be made to account for many things, they seem hardly adequate to explain the whole of the 
phenomena observed at Tedworth, or in many other cases of poltergeist hauntings that have been investigated. ${ }^{1}$ Certain it is that in $\mathbf{M r}$. Mompesson's house there were children, that children are naturally mischievous, and that the phenomena appeared in a way to centre about the children-a feature which it is interesting to note seems frequent in cases of this sort. But it is extremely improbable, to say the least, that, even if the children could have accomplished, by means of trickery, the things recorded, they could have persisted in this for so long without being found out. It is, of course-to follow another line of thought-highly probable that the heightened state of imagination on the part of the members of the household produced by the initial phenomena may have given rise in the latter stages to things being heard and seen which had no existence outside their imaginations; and in this category we are certainly inclined to place, for instance, the apparition which Mr. Mompesson's man-servant ${ }^{2}$ asserted that he had seen. Again, however, the solution of the

1 See, for example, The Epworth Phenomena, to which are appended certain Psychic Experiences recorded by John Wesley in the pages of his Journal. Collated by Dudley Wright (London, 1917).

Sad. Trium., ed. cited, Part 2, pp. 67 and 58. 
problem fails to be achieved, for this theory does nothing to explain the fundamental phenomena, but serves only to rid them of some adventitious trappings.

Amongst the cases observed at Tedworth of the movements of objects without physical cause, one is of particular interest. To quote Glanvill's words :

"A Bed-staff was thrown at the Ministerr which hit him on the Leg, but so favourably, that a lock of Wool could not fall more softly, and it was observed, that it stopt just where it lighted, without rolling or moving from the place." 1

Similar phenomena in which objects have appeared to move as though thrown, but at the same time have come to rest as though rapidly carried, have been observed at spiritualistic seances in recent years. Perhaps the most satisfactory attempt at explanation is the late Dr. Crawford's theory of psychic cantilevers. Another point of great interest concerning the Tedworth phenomena is the fact that they showed evidence of being produced by means of an agency not destitute of intelligence. Glanvill writes of the disturbance, " that it would exactly answer in Drumming,

1 Sad. Trium., ed. cited, Part 2, pp. 51 and 52. 
any thing that was beaten or called for," 1 and he also records that on a certain occasion :

"When many were present, a Gentleman of the Company said, Satan if the Drummer set thee to work, give three Knocks and no more; which it did very distinctly, and stopt: Then the Gentleman knockt to see if it would answer him as it was wont, but it did not : For farther trial, he bid it for confirmation, if it were the Drummer, to give five Knocks and no more that Night, which it did, and left the House quiet all the Night after." "

Unfortunately the line of investigation suggested by this experiment does not appear to have been continued, otherwise some important and interesting results might have been obtained, similar to those of modern spiritualism.

Glanvill himself spent a night at Tedworth, and although the more striking phenomena did not take place while he was there, he was able to observe sufficient to satisfy his own mind. King Charles, it is recorded, sent some gentlemen to investigate the matter; but they appear to have been unfortunate, since whilst they were at Tedworth no phenomena occurred, a fact
1 Ibid., Part 2, p. 52.
2 Ibid., Part 2, p. 53. 
which, though it may have discredited the whole matter in their eyes, can hardly be regarded as negativing the testimony of those who observed the happenings on other occasions.

The psychic nature of the poltergeist seems established, but it is a far cry from this to a complete explanation of the phenomena. One school of thought would have us believe that they are produced by "elementals"; but, failing evidence for the existence of these strange spiritual beings, the theory does not appear to be very satisfactory. Mr. Ralph Shirley, ${ }^{1}$ in a recent discussion of the subject, suggests as more likely that poltergeist phenomena are produced by the discarnate spirits of children, though he is quite alive to the fact that, if such phenomena can be brought about by discarnate spirits, there is no $a$ priori reason why they should not be effected by incarnate spirits-since the difference between man here and man hereafter may well be supposed to reside not in his powers, but only in his consciousness of them-and, as concerns the Tedworth phenomena, he is inclined to adopt this latter alternative and to accept the implication

1 Ralph Shirley: "Notes of the Month: The Polter. geist; a Study in Badly Behaved Ghosts," The Occult Review (London), vol. xxvii, pp. 1-18 (January, 1918). 
of the-vagrant drummer in the affair. Mr. J. Arthur Hill suggests still another possible theory. Whilst he is of the opinion that "some of these physical phenomena may be caused by the action of the subliminal will," by methods as yet entirely unknown, in other cases he is " compelled to go beyond the subliminal will of the living people concerned," and to assume the operation of the will of the so-called dead; and he suggests that the apparent aimlessness of the phenomena may be accounted for, if we suppose this will to be operative during a sort of dream-state; the happenings thus being "an objectified dream of the dead." 1

The rest of Glanvill's relations are mainly contemporary ghost-stories and supposed cases of witchcraft, together with a few instances (though of much less interest than the Tedworth case) of haunted houses. The value of the ghost-stories is unfortunately rather discounted by the fact that, with one exception, they are not first-hand, and modern investigation has shown how unreliable, even when given in entire good faith, second-hand evidence may be. The first-hand ghost story is one related by

1 See his Introduction to The Epworth Phenomena, p. xviii. 
Thomas Goddard of Marlborough, Wiltshire, a poor working man and-it should be notedan epileptic. His account is, that on three occasions during November, 1674, the ghost of his father-in-law appeared to him, caused him to repay on his (the ghost's) behalf a loan of twenty shillings, which Thomas could ill afford, and confessed to a murder, evidence for which was not forthcoming. The sincerity of Goddard is beyond question; but to us the story reads rather as though the man had been hoaxed.

Most of the witchcraft cases dealt with are cases which came before Glanvill's friend Robert Hunt, in his capacity of a justice of the peace, and are based upon the records made by him at the time. Sir Walter Scott writes of this gentleman as follows :

"A pragmatical justice of peace in Somersetshire commenced a course of enquiry after offenders against the statute of James I, and had he been allowed to proceed, Mr. Hunt might have gained a name as renowned for witchfinding as that of Mr. Hopkins; but his researches were stopped from higher authority - the lives of the poor people arrested (twelve in number) were saved, and the country remained at quiet, though the supposed witches 
were suffered to live. The examinations attest some curious particulars . . for among the usual string of froward, fanciful, or, as they were called, afflicted children, brought forward to club their startings, starings, and screamings, there appeared also certain remarkable confessions of the accused, from which we learn that the Somerset Satan enlisted his witches, like a wily recruiting sergeant, with one shilling in hand and twelve in promises ; that when the party of weird-sisters passed to the witch-meeting they used the magic words, Thout, tout, throughout, and about; and that when they departed they exclaimed, Rentum, Tormentum! We are further informed that his Infernal Highness, on his departure, leaves a smell, and that (in nursery-maid's phrase) not a pretty one, behind him." 1

We do not think, however, that Scott's remarks are quite just, for, in the state of knowledge (or rather ignorance) concerning psychology which prevailed at the time, the evidence for the guilt of the parties implicated in these trials must have seemed remarkably strong. Very naturally great stress was laid upon the confessions of the accused persons, which show

1 Sir Walter Scott: Letters on Demonology and Witchcraft, with an Introduction by Henry Morley, Second Edition (London, 1885), pp. 215 and 216. 
a remarkable degree of uniformity; but present-day knowledge concerning the power of suggestion tends very strongly to deprive these confessions of evidential value. A priori it seems incredible that a person should confess to an imaginary crime in full knowledge of the terrible punishment that would be meted out in consequence; but the study of hysteria affords absolutely parallel cases to those of self-accused witches; and suggestion, acting upon a feeble mentality still further enervated by fear, or on the mind of a hysteric in which the desire for notoriety had become dominant, is sufficient to account for very many of these confessions. There are, indeed, many reasons for connecting the phenomena of witchcraft with those of hysteria ; in examining witches it was, for example, customary to seek for a spot on the body insensitive to pain: these anæsthetic spots are common in hysterical patients. Such patients, moreover, are known in some instances to have a tendency towards self-injury. There is a case on record, for example, of a man who deliberately destroyed the sight of one of his eyes by introducing irritants into it, and had commenced to damage the other before the nature of his malady was discovered; and the finding of nails, pins and 
thorns in the bodies of the bewitched, or of their romiting such things, can, it would seem, be explained along the same lines. It seems probable, therefore, that in many instances, at any rate, both the witch and her victim were sufferers from the same malady manifesting itself in different forms. The latter was usually a child; and the statement of a supposed bewitched child that an apparition of the accused had appeared to him or her was regarded as evidence of the former's guilt, which no alibi could overthrow-a most unjust procedure, and one which must have proved very tempting to a child of malicious imagination. Indeed, during the early part of the seventeenth century at any rate, there was a tendency to ascribe any inexplicable illness or other misfortune to witchcraft, and any ill-favoured or eccentric old woman ran the risk of being condemned as a witch upon the most unsatisfactory evidence. It must, in fact, be admitted that the history of witchcraft is one of the darkest in the annals of Occultism and one of the least satisfactory from the evidential point of view. At the same time, however, seeing that the possibility of witchcraft was at one time universally accredited, it stands to reason that amongst the believers there must have been 
some evilly disposed persons who endeavoured to practise and to become proficient in the art. The question for us is, Did they succeed in accomplishing any results other than those existing in their own diseased imaginations? There is evidence for answering this question in the affirmative. Recent psychical research, for example, has proved conclusively the possibility of a person causing an apparition of himself to appear to others, though whether such apparitions are to be regarded purely as telepathic hallucinations, or as having an objective reality and being something in the nature of an astral or etheric double, is a matter for further research. Perhaps both types of apparitions are possible. One case of witchcraft recorded by Glanvill seems to involve a phenomenon of the latter type and to demand something more than mere hysteria for its explanation. According to this account, Richard Jones, a bewitched child, called out, whilst in a fit, that he saw his tormentor, a woman named Jane Brooks, at a certain spot, at which spot a man who was present immediately struck with a knife. To continue in Glanvill's own words :

“ Upon which the Boy cryed out, ' O Father, 


\section{PSYCHICAL RESEARCH}

couz Gibson hath cut Jane Brook's hand, and 'tis Bloody.' The Father and Gibson immediately repaired to the Constable a discreet Person, and acquainting him with what had passed, desired him to go with him to Jane Brook's House, which he did. They found her sitting in her Room on a Stool with one hand over the other. The Constable askt her how she did? She answered, not well. He askt again why she sat with one hand over the other. She replied, she was wont to do so. He enquired if any thing was amiss with her Hand? Her answer was, it was well enough. The Constable desired he might see the hand that was under, which she being unwilling to shew him, he drew it out and found it bloody according to what the Boy had said. Being askt how it come so, she said 'twas scratched with a great Pin." 1

Unless this is to be explained away as pure coincidence, which the woman's hesitancy to admit her hurt seems to prohibit, it must be regarded as constituting a case of an objectively real apparition of the living. We are reminded of the theory of repercussion, according to which, spiritualists assert, any damage done to a materialised spirit is transferred to the medium. To a sceptical mind, this theory

I Saducismus Triumphatus, edition cited, Part 2, p. 64. 
seems rather as though it were devised to prevent the exposure of fraud; but, on the other hand, there is not wanting evidence to support it; and a true scepticism, we suggest, consists in maintaining an open mind and pledging one's faith only in research. The case of Jane Brooks contains some other interesting features. It was alleged that the boy, Richard Jones, would fall into a fit if Brooks merely touched him. One of the justices, ${ }^{1}$ who appears to have been a man of sense, put this to the test by blindfolding the boy and causing Brooks to touch him when he (the justice) ostensibly called upon some other person so to do, and conversely. The extraordinary thing is that the allegation was thereby proved to be correct.

On the whole, it must be said that the records of witchcraft comprise a great deal of curious psychical or, at any rate, psychological information, though the interpretation to be put upon them is not that of seventeenth century belief. This remark is true on the whole, we think, of Glanvill's collection of records. In

1 These were Robert Hunt and John Cary; but the case is not one of those referred to in the passage quoted from Sir Walter Scott. Jane Brooks was condemned and executed, March, 1658. 


\section{PSYCHICAL RESEARCH}

spite of his recognition of the possibility of the operation of good spirits in the affairs of this world, he was perhaps too prone to see the hand of the devil, or, at any rate, of his satellites, in the psychic phenomena he recorded. It was, of course, the fault of his age, and we must not attach any particular blame to him for it. There was a tendency to include all psychic phenomena under the category of witchcraft, or, at any rate, to regard those of witchcraft as the most characteristic, a tendency which even to-day persists to some extent within the Church. To this fact must, perhaps, be ascribed the outstanding defect of Glanvill's investigation of matters psychic, namely, that he was, as concerns them, an observer and recorder-as, for example, an astronomer is necessarily an observer and recorder of the facts of his science-not an experimenter in the sense in which a chemist is an experimenter in the domain of chemistry. Two centuries passed before men fearlessly took up the thorough investigation of the dark and dangerous world that lies beyond (or should it be within ?) this, and dared to experiment in the domain of psychic phenomena. Glanvill's book, when subjected to the searching light of modern criticism, may fail to carry conviction 
94 JOSEPH GLANVILL

to the incredulous. But he set his foot in the right direction, even if he failed to travel far. For his method all honour is due to him. It has remained for The Society for Psychical Research to perfect it. The gain in knowledge already achieved is great; the promise is still greater.

\section{THE END}




\section{THE "MYSTICS and OCCULTISTS" SERIES}

Crown 8vo, Limp Cloth, 1s. 6d. net per volume.

\section{THEOPHRASTUS PARACELSUS}

Medireval Alchemist. By W. P. Swalnson.

Contents.-Early Life and Travels-Wanderings and DeathAs above, So below-Doctrine of Signatures-NecromancyOrigin of Diseases-Magic-Alchemy-Astrology-Comparison with other Mystics-A Christian Occultist.

"The life of Paracelsus, his writings and teachings, form a subject of perennial interest, all the more fascinating on account of the mysterious and wonderful element which enters into it."-The Theosophist.

\section{EMANUEL SWEDENBORG}

The Swedish Seer. By W. P. Swainson.

Contents. - Scientific Education - Seership - Character Doctrine of Correspondence-The Divine Humanity-Heaven and Hell-The New Jerusalem.

This book gives in a concise form the life of the Swedish Seer, and an outline of his system of philosophy.

\section{FRANZ ANTON MESMER}

His Life and Teaching. By R. B. Ince.

Contents. - Early Theory and Practice - Mlle Paradis Mesmer in Paris-Mesmer's Fight with the Doctors-Mesmer and the Royal Society of Paris-Mesmer's Theory and MethodSuccess or Failure?

"Mesmer's Curative Methods will be found interesting by magnetic healers and hypnotists."-Inter. Psychic Gazette.

\section{ROGER BACON}

The Father of Experimental Science. By H. Stanley RrDgRovr, B.Sc. (Lond.).

"The Analysis of Roger Bacon's claim to greatness is as sound as the whole book is interesting."-Sheffield Independent.

READY SHORTLY

CORNELIUS AGRIPPA. By Lewis Spence.

ANDREW JACKSON DAVIS, M.D.

A Study of the Pougkeepsie Seer. By W. B. PICKen. GIORDANO BRUNO. By Eva M. Martin.

WILLIAM RIDER \& SON, LTD., 8-11 Paternoster Row, E.C.4 


\section{RIDER'S PUBLICATIONS}

\section{MODERN SAINTS AND SEERS}

Translated from the French of Jean Finot, by EvaN

MARRETT. Crown 8vo, cloth, 4s. 6d. net.

A vivid account of the many strange religious sects of Russia, including sketches of Tolstoi, Rasputin, etc. Mormonism, Christian Science, and other religious organisations are also reviewed.

"Intensely interesting." -Ladies' Field.

\section{OCCULTISTS AND MYSTICS OF ALL}

AGES. By Ralph Shirley, Author of "A Short Life of Abraham Lincoln," "The New God," etc. Crown 8vo, cloth, illustrated, 4s. 6 d. net.

"This book may not inaccurately be described as romanceusing the word in its widest understanding. It deals with the deeds and the sayings of wonderful people, who each in turn helped to mould and to remake the state of the world. . . . Can be cordially commended to all lovers of these engrossing subjects."

-Ladies' Field.

\section{THE INNER TEACHING AND YOGA}

By Charles Wase. Crown 8vo, cloth, 4s. 6d. net.

An attempt to make the deeper philosophy of the East available to the Western World, and to unify the standpoint of the Eastern and Western Schools of Thought.

\section{THE INFLUENCE OF THOUGHT ON HEALTH, WEALTH AND HAPYIN $\triangle S$ S. By H.} ERnEST HUNT, Author of "Nerve Control," "A Manual of Hypnotism," "Self-Training," etc. Crown 8vo, cluth, 5s. net.

The author shows that by the regulation and control of thought the greatest benefit mav be derived in the directions of health, personal efficiency, and general happiness.

\section{MASTER KEYS OF LIFE AND DEATH}

By CAPT. Carey, R.N. Crown 8vo, cloth, 3s. 6d. net.

"Master Keys" explains in simple English the occult teachings of Theosophy and Spiritualism.

\section{WILLIAM RIDER \& SON, LTD., 8-11 Paternoster Row, E.C.4}



- 


\title{
AnEM SECT.
}

\author{
PLEASE DO NOT REMOVE \\ CARDS OR SLIPS FROM THIS POCKET
}

\section{UNIVERSITY OF TORONTO LIBRARY}

B

1201

G54R4
Redgrove, Herbert Stmnley Joseph Glanvill and psychical research in the seventeenth century 
260 80.

His

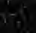

7.

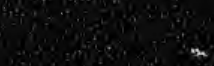

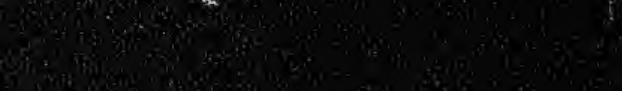
2.

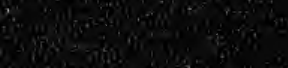

C.1.

(8)

$=49 y^{2}$

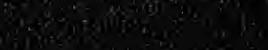

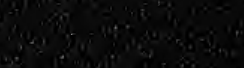

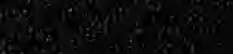

(6)

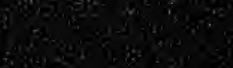

$\log (4,2)$

4. 